


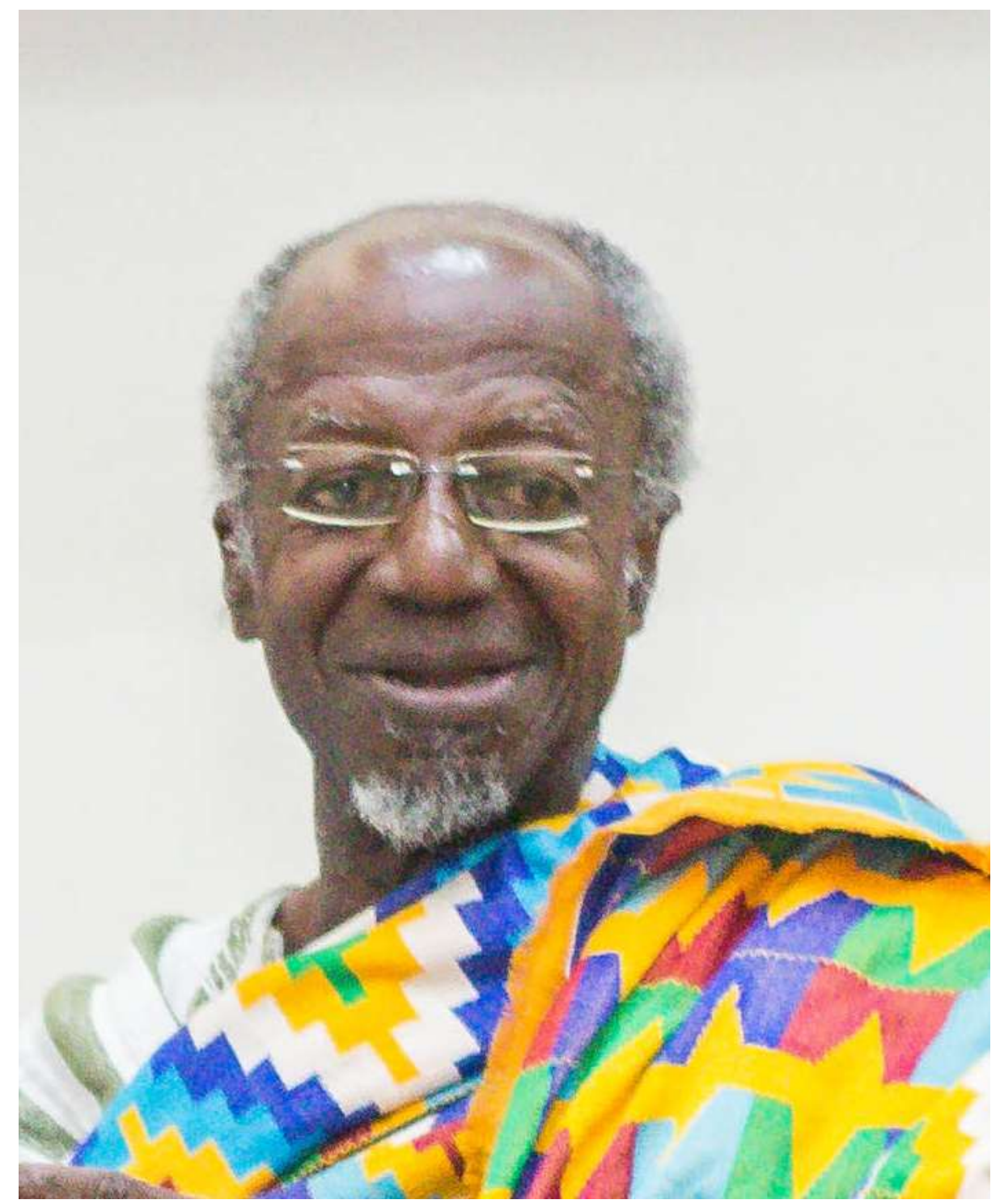

PROFESSOR ATTA GYAMFI BRITWUM 


\section{THE BILINGUAL LITERARY JOURNAL OF THE FACULTY OF ARTS UNIVERSITY OF CAPE COAST}

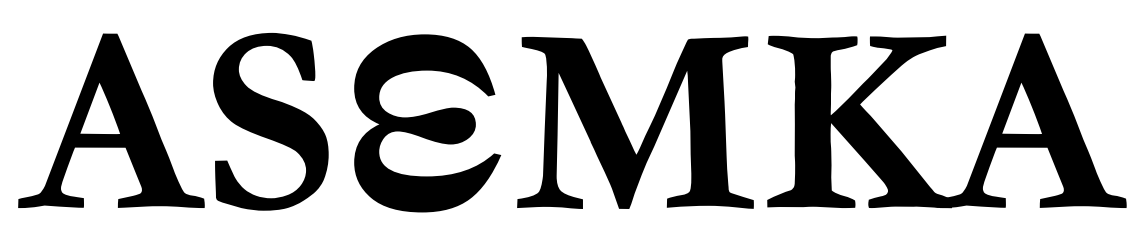

NUMBER 10

SEPTEMBER 2020

\section{EDITORIAL COMMITTEE}

Editor-in-Chief: Prof. Samuel Awuah-Nyamekye (Ph.D.)

Editor: $\quad$ Prof. Mawuloe Koffi Kodah (Ph.D.)

Associate Editors: Dr. Samuel Kwesi Nkansah

Dr. Mrs. Theresa Addai Munumkum

Dr. Isaac Mwinlaaru

Business Editor: Rev. Sr. Dr. Matilda Alice Nsiah

\section{EDITORIAL STAFF}

Mr. Stephen Owusu-Amoh

Mr. Isaac Kweku Grantson

\section{EDITORIAL ADVISORS}

Prof. Kwadwo Opoku-Agyemang, University of Cape Coast.

Prof. Joseph B. A. Afful, University of Cape Coast.

Prof. Raymond N. Osei, University of Cape Coast.

Prof. Richard V. Cudjoe, University of Cape Coast.

Prof. Victor K Yankah, University of Cape Coast.

Dr. Mousa Traore, University of Cape Coast. 


\section{ACKNOWLEDGEMENTS}

We acknowledge the contribution of the underlisted members of the Department of French who did preliminary editorial work on the papers:

Dr. Anthony Y.M. De-Souza (Chairman)

Prof. Raymond N. Osei

Prof. Mawuloe K. Kodah

Dr. Sylvester P. Krakue

Mr. Ofosu Addo-Danquah

Mr. Micheal Donkoh (Secretary)

\section{SUBSCRIPTION}

Assmka is published twice in the Academic year by the Faculty of Arts, University of Cape Coast. The annual out-of-Ghana subscription rate, including air-postage, is US\$29 for individuals, and US\$ 59 for institutions and libraries. Single issue rate for individuals is US\$18. Claims for copies not received must be made within three (3) months following an issue's publication. Correspondence should be addressed to:

The Editor, Assmka

Department of French

Faculty of Arts

College of Humanities and Legal Studies

University of Cape Coast

Cape Coast

Ghana, West Africa

Email: asemkajournal@ucc.edu.gh

\section{ADVERTISING}

Advertising rate, size specifications and related information are available upon request. Please, contact the General Editor for more information.

\section{SUBMISSIONS}

Assmka is an internationally-refereed journal of the Humanities. It publishes scholarly and imaginative articles in Literature, Language, and Culture generally, including, Orature, Film, Theatre, Music and Art. Essays, Interviews, Book Reviews, Poetry, Short Prose Fiction and Drama are welcome. Submitted manuscripts, in English and French, must be prepared in accordance with the most recent of APA or MLA style manual, where applicable. The author's identity and address may appear only on the cover- 
page and nowhere else within the submitted manuscript. All manuscripts should be submitted electronically through:

asemkajournal@ucc.edu.gh

Manuscript will be duly acknowledged within two (2) months of receiving them. Individuals whose works are accepted for publication may provide Assmka with a brief bio-data. The Editors cannot be held liable for lost or damaged manuscripts. Material published by Assmka does not necessarily represent the views of the Journal's Editors, Staff, Financial Supporters or the University of Cape Coast and its affiliates. These parties disavow any legal responsibility related to all submitted material.

\section{BACK ISSUES}

Back issues of Ascmka that are in stock may be ordered from the Editor at US\$20 per copy.

\section{GRANT SUPPORT}

Assmka is funded through grants from the Office of the Dean, Faculty of Arts; the Publications' Board; and the Office of the Vice-Chancellor, University of Cape Coast, Cape Coast, Ghana.

No part of this Journal may be reproduced, stored in a retrieval system, or transmitted in any manner whatsoever without express permission from the Editors, except in the case of brief quotations embodied in critical Articles and Reviews.

Copyright (C2020 by The Editors and The Faculty of Arts, University of Cape Coast. The cover and page design elements were inspired by the Adinkra symbols of Ghana. 


\section{DEDICATION \\ PROFESSOR ATTA GYAMFI BRITWUM}

Professor Britwum is a man of many parts. He is as much at home with Marxist Economic Theory and Feminist Sociological Thoughts, as he is with French and Francophone Literatures. He is a great teacher and Administrator of international acclaim. The Editors dedicate this special issue of Assmka to his honour. 


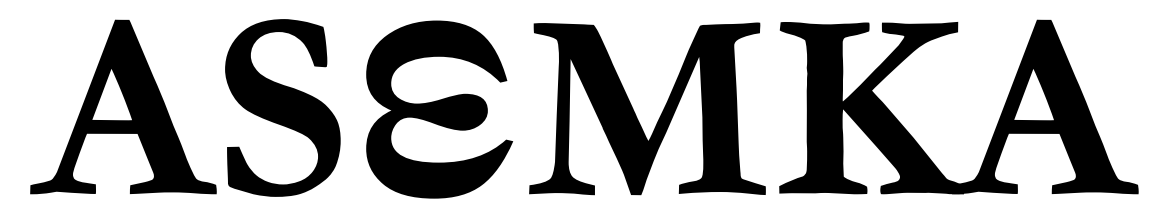

NUMBER 10

SEPTEMBER 2020 


\section{CONTENTS}

$\begin{array}{llll}\text { Editorial Committee } & \sim & \sim & \sim i i \\ \text { Editorial Staff } & \sim & \sim & \sim i i \\ \text { Editorial Advisors } & \sim & \sim & \sim i i \\ \text { Acknowledgements } & \sim & \sim & \sim i i i \\ \text { Subscription } & \sim & \sim & \sim i i i \\ \text { Advertising } & \sim & \sim & \sim i i i \\ \text { Submissions } & \sim & \sim & \sim i i i \\ \text { Back Issues } & \sim & \sim & \sim i v \\ \text { Grant Support } & \sim & \sim & \sim i v \\ \text { Dedication } \sim & \sim & \sim & \sim \\ \text { Foreword } \sim & \sim & \sim & \sim x \\ \text { Assmka: Editorial } & \sim & \sim & x i-x v i i\end{array}$

Articles

First Section - French

Britwum, A. G.

Insuffisances Théoriques Des Damnés De La Terre De

Frantz Fanon

$\sim$

$\sim 2-15$

Kodah, M. K.

Disculpation de Dieu dans le malheur des hommes:

Une lecture critique de Gouverneurs de la rosée de

Jacques Roumain $\sim \sim \sim 16-31$

Addo-Danquah, $O$.

Le récit de pensées: Une analyse comparative de Vol de nuit d'Antoine de Saint-Exupéry et La Condition humaine d'André Malraux

Kodah, M. K. \& Togoh, A. A. X.

Réactions des femmes face au conflit de genre dans C'est le soleil qui m'a brûlée et Tu t'appelleras Tanga de Calixthe Beyala

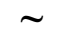

$\sim$

$\sim \quad 45-59$ 
Kudi, M. D.

La Littérature francophone face aux médias de télécommunication : Une nouvelle dynamique de la création romanesque, le cas de L'Énigme de retour et Tout bouge autour de moi de Dany Laferrière $\sim \quad$ 60-72

Gli, $M$.

Les faces du bonheur dans Vol de nuit d'Antoine de Saint-Exupéry $\sim \sim 73-85$

Krakue, S. P.

Christ haïtien : Gouverneurs de la rosée et La Bible $\sim 86-93$

Afari, E. S. K. \& Yegblemenawo, C. A. A.

Apports de la télésérie à l'amélioration de la compétence d'expression orale du FLE à l'école normale $\sim 94-116$

Bationo, J.-Cl.

Didactique de la littérature et littérature didactique:

l'exemple de la littérature africaine francophone en classe de langues étrangères au Burkina Faso

Second Section - English

Krakue, S. P.

Quod erat demonstrandum: A comparative study of narrative technique in Ama Ata Aidoo's Changes and Albert Camus'

Les justes (The Just Ones) 〜 $\sim$ $133-141$

Adjandeh, E. A.

Analysis of Wole Soyinka's Trials of Brother Jero in Relation to Ghanaian Religious Discourse

Sam, C. A.

Decolonizing the Postcolony: Of Men, Spatial Politics and the New Nation in WA Thiongo's Wizard of the Crow.

Kambou, M. K. \& Traore, S. A.

Manipulation and the popular uprising in Burkina Faso in 2014. $\sim \quad \sim 172-189$ 
De-Soura, A. Y.M.

Test-taking Strategies of University of Cape Coast Students of

French as a Foreign Language: a Case Study $\sim 191-216$

Kambou, M. K. \& Soma, L.

Local Culture and EFL Vocabulary Learning $\sim \quad 217-238$

Kabore, A. \& Nazortin, C.

Critical Analysis of the Place and Importance of Literature in the Teaching / Learning of English and in School Leaving Certificate Examination in Burkina Faso from 1985 to 2018

Malgoubri, I., Sawadogo, M. \& Kambou, M. K.

Digital Audio-visuals Aids and Listening in English as a

Foreign Language Classrooms

Osei, R. N. \& Inusah, $H$.

A Critique of the Images of Heaven in the Scriptures of the

Abrahamic Religions: An Existentialist Perspective $\sim$ 270- 282

Negedu, A. K.

Lexical Gaps and Ideological Shift in the Translation of

Chinua Achebe's Things Fall Apart as "Le Monde

S'effondre" in French $\sim \sim 283-297$

Talburt, $T$.

Political Transformation and Development in Africa:

Lessons from Achebe's Things Fall Apart

$\sim 298-313$ 


\section{FORWORD}

All the papers in this Volume were presented at a three-day Conference in honour of Professor Atta Gyamfi Britwum who turns eighty years in March 2021. Most of those years he spent at University of Cape Coast, having cut his teeth as a young lecturer in French language and Literature-in-French in 1974. After many years of an illustrious career in teaching, publication and extension, he bowed out at age seventy, but he didn't get the well-deserved rest he was entitled to; he continues to support his Department and the University as a whole. Today, Professor Britwum's name is associated with high standards of professionalism which earned him the nickname 'L'oracle'. Indeed, it is impossible to find another name universally acknowledged as embodying the excellence in French education offered at the Department of French, University of Cape Coast.

The decision to honour Professor Britwum couldn't have been taken at a more appropriate time. It was planned to coincide with the fiftieth anniversary of the publication of the Beautyful ones are not yet Born, Ayi Kwei Armah's first novel. Britwum never grew tired of reading, teaching and examining it. Such was his respect for Armah's craft. So, the three-day Conference was as much a celebration of Armah's contribution to the shaping of the African novel as it was a tribute to Professor Britwum's work as a teacher of literature of immense influence.

One only has to look at the titles of the papers published in this Volume to get an idea of how deep his influence runs at UCC and beyond. Most of the contributors once upon a time sat at the master's feet, but are now scholars in their own right keeping the flame of French scholarship burning bright (George Cooper: "Polished in a high degree, as each froggie ought to be/Now they sit on other logs, teaching other little frogs.") A good number of the papers are on Literature, nonetheless not limited to Armah's works. No Surprise there. Nevertheless, there are Language papers there too. No surprise here either, for the man to whose honour the Volume is dedicated is equally at home in both Language and Literature

\section{Lawrence $K$. Owusu-Ansah,}

Department of English, UCC.

A Disciple 


\section{$A S E M K A:$ EDITORIAL}

This Special Edition of $A S E M K A$, a bilingual literary journal of the University of Cape Coast, is published in honour of Prof. Atta Gyamfi Britwum, a revered Associate Professor of Francophone African Literature and Civilisation in the Department of French, U.C.C. It contains twenty (20) papers centred on diverse areas of teaching and research in the Humanities and on the theme of the Conference - Literature and the Humanities in the 21 Century: Interdisciplinary Perspectives - held in his honour by the Department of French, University of Cape Coast, Ghana, $13^{\text {th }}-15^{\text {th }}$ Mars, 2019. To reflect Prof. Britwum's area of research interest, the essays are arranged in two sections according to his dominant medium of instruction (French language) and speciality (Literature and Civilisation), followed by those in English language. The first section consists of a set of nine (9) essays in French spanning between themes in Literature and Language. The second section is made up of a set of eleven (11) essays in English which examine issues in literary studies, Language and Didactics, ICT and French Education, Philosophy, and Translation, among others. This special arrangement is however representative of the bilingual nature of the Journal.

\section{First Section}

Britwum, A. G.'s paper titled, “Insuffisances Théoriques Des Damnés De La Terre De Frantz Fanon", presents the Fanonian perspective as a complement to the African nationalism that informed anticolonial struggles. The study posits that African nationalism, populist in nature, for failing to target the capitalist economic base, which defines colonialism, ended up strengthening it. It concludes that Fanon's anticolonialist perspective, despite its overt radicalism, is not designed to allow a "bottom-to-top change" in colonial / capitalist society.

Kodah, M. K.'s paper titled, "Disculpation de Dieu dans le malheur des hommes: Une lecture critique de Gouverneurs de la rosée de Jacques Roumain", puts into question the responsibility of God in the suffering of men on earth and the capacity of man to make and unmake himself. The study aims at absolving God of the guilt of the miseries of men, and also questioning the atheistic or anti-religion denunciation of this narrative 
text since its publication. The study is accomplished through a critical reading and a thoughtful analysis of Jacques Roumain's Gouverneurs de la rosée within the analytical structure of literary studies and sociocriticism.

Addo-Danquah, O.'s paper, "Le récit de pensées : Une analyse comparative de Vol de nuit d'Antoine de Saint-Exupéry et La Condition humaine d'André Malraux", drawing inspirations from theorists such as Léon Edel (1961) and later Dorrit Cohn (1981), examines what Antoine de Saint-Exupéry's Vol de nuit by and André Malraux's La Condition bumaine respectively can offer on the side of representations of the interior life. The study is posited within the framework of narratological theories.

Kodah, M. K. \& Togoh Tchimavor, A. A. in "Réactions des femmes face au conflit de genre dans C'est le soleil qui m'a brûlée et Tu t'appelleras Tanga de Calixthe Beyala" examine the reactions of women to gender conflict in Calixthe Beyala's C'est le soleil qui m'a brulée and Tu t'appelleras Tanga. The study critically reflects on the various ways women in Beyala's C'est le soleil qui m'a brulée and Tu t'appelleras Tanga react to oppression and exploitation resulting from patriarchal domination. It therefore examines the sources and nature of this conflict, and how women react to it in the two novels. The study points to the fact that, much as conflict emanating from patriarchal oppression and male's domination in human societies is inimical to the rights of women, the methods used by the latter to free themselves from this state of being remain questionable, in that, these methods defy rational thinking and are also a kind of reversal oppression and domination which are equally unacceptable.

Kudi, M. D.’s paper, “La Littérature francophone face aux médias de télécommunication: Une nouvelle dynamique de la création romanesque, le cas de L'Énigme de retour et Tout bouge autour de moi de Dany Laferrière", seeks to examine how pertinent painting, photography, television, telephone etc. are to the production of the contemporary Francophone novel. The study focuses on L'Énigme de retour (2009) and Tout bouge autour de moi (2011). The analysis is based on the perspective of literary intermediality propounded by Jürgen E. Muller which is characterised by an interaction between telecommunication media and literary text. The study establishes through these selected novels that these media forms are not simply another form of expression in the novel but rather a lens through which the story is narrated. 
Gli, M.'s paper titled, "Les faces du bonheur dans Vol de nuit d'Antoine de Saint-Exupéry", analyses the faces of happiness in Antoine de Saint-Exupéry's Vol de Nuit. The study is conducted through thematic approach. This approach is complemented by Maslow's theory of human needs. The collection of data or the collection of information is purely documentary. The study therefore seeks to establish a link between individual happiness and collective happiness in Saint-Exupéry's selected narrative text.

Krakue, S. P.'s paper, “Christ haïtien : Gouverneurs de la rosée et La Bible", attempts to question Jacques Roumain's Gouverneurs de la rosée in order to elucidate the novelist's use of the biblical text in his creative activity. The study demonstrates that Jacques Roumain's narrative text turns out to borrow biblical ideas not only to develop his plot but also to design his main character.

Afari, E. S. K. \& Yegblemenawo, C. A. A. in “Apports de la télésérie à l'amélioration de la compétence d'expression orale du FLE à l'école normale." examine the impact examine the impact of the use of serial movies as teaching aid on oral expression of French language learners in Colleges of Education in Ghana with the aid of smartphones. The study discovers that the use of serial movies in teaching French boosts learners' performance in oral communication. It therefore recommends that serial movies could be used in teaching French language lessons in order to enhance the oral communication competencies among learners.

Bationo, J.-Cl.'s paper titled, "Didactique de la littérature et littérature didactique : l'exemple de la littérature africaine francophone en classe de langues étrangères au Burkina Faso", shows not only how to teach literature in language class but also how to use didactic literature to develop social skills among learners to reduce vandalism, school violence, negative stereotypes, misunderstandings of intercultural nature while cultivating social peace and living together in a context of internationalization, globalization and digital revolution. The paper focuses on francophone African Literature and posits that methodological approach used for the didactic transpositions of literary content is based on the new orientation and the redefinition of the objectives of language teaching and on the didactic models of the aesthetic reception of didactics of literature which requires putting the learner in intensive interaction with the text and motivating him/her to express himself/herself on his/her reading experiences. 


\section{SECOND SECTION - ENGLISH}

Krakue, S. P.'s paper titled, “Quod erat demonstrandum: A comparative study of narrative technique in Ama Ata Aidoo's Changes and Albert Camus' Les justes (The Just Ones)", demonstrates through textual analysis, how in Ama Ata Aidoo's Changes and Albert Camus Les justes, the authors resort to a specific form of irony to bring the discussion of issues raised to a conclusion. The technique consists in demonstrating clearly a huge discrepancy between a "fine" idea and its practical usefulness. Both authors successfully use narrative technique. Albert Camus demonstrates the hollowness of the idea of fighting for justice through revolutionary violence and Ama Ata Aidoo similarly demonstrates the fatuousness of the theory of women-emancipation-through-polygamy.

Adjandeh, E. A. analyses selected reports in Ghanaian media in relation to the clergy and identifies how Wole Soyinka's theme is reflected in these media in her paper titled, "Analysis of Wole Soyinka's Trials of Brother Jero in Relation to Ghanaian Religious Discourse". The study seeks to examine the extent to which themes in Soyinka's Trials of brother Jero play out in religious discourses in Ghana. The global nature of the issues problematized by Wole Soyinka also comes out through this study as the work set in Nigeria is analyzed in relation to the selected articles set in Ghana. The paper relies on a content analysis of Trials of Brother Jero and similar themes presented in the selected articles, and makes a few recommendations on how these religious issues could be partially, if not wholly, resolved in Ghana.

Sam, C. A.'s paper, "Decolonizing the Postcolony: Of Men, Spatial Politics and the New Nation in WA Thiongo's Wizard of the Crow", examines how Ngugi Wa Thiongo's Wizard of the Crow blatantly explores Africa's complicity in a seemingly cyclic colonization in the $21^{\text {st }}$ century and its attendant consequences for the total liberation of Postcolonial Africa. The study examines the correlation between masculine representations, spatial reorganization and futurity as alternative ways in thinking about Africa's future through Bakhtin's theory of the carnival and other such concepts as polyphony and the grotesque. The result of the analysis is that the correlation between forms of communities and forms of masculinities is an indication of a vision of hope for Postcolonial Africa. 
Kambou, M. K. \& Traore, S. A. in "Manipulation and the popular uprising in Burkina Faso in 2014", analyse the different discourses in the build-up to the popular uprising in Burkina Faso on the $30^{\text {th }}$ and $31^{\text {st }}$ October 2014. It attempts to clarify how political and civil society leaders use language and other non-linguistic elements to influence the ordinary citizens' minds and, indirectly, their actions. The analysis is premised on Van Dijk's (2006) Sociocognitive approach. The paper analyses the cognitive, the social and the discursive dimensions of manipulation in six political speeches (two speeches from Civil Society, two from the ruling party and two from the political opposition). The results suggest that the three groups manipulated their audiences, and finally, the ruling party lost following the resignation of the then Head of State, making way for a Transition government to take over the reins of governance.

De-Souza, A. Y. M.'s paper “'Test-taking Strategies of University of Cape Coast Students of French as a Foreign Language: a Case Study.” seeks to provide a description of test-taking strategies that may inform teaching and learning of French for better output in tests against the background that Ghanaian students of French as a foreign language deploy strategies that are not adequate enough in answering test items in French. The study examines data gathered right after a French test by level 200 students, using recollective verbalization protocols.

Kambou, M. K. \& Soma, L. examine in their paper titled, "Local Culture and EFL Vocabulary Learning”, the influence of learners' culture on foreign language vocabulary. The paper seeks to demonstrate that there is a link between culture and lexico-semantic errors committed by learners of English as a foreign language among Dioula speaking students in Burkina Faso. A language test composed of two written activities was used as the data collection instrument. The results revealed that the Dioula speakers' English is influenced by their culture. These results have some pedagogical implications. They, therefore, suggest that we adapt the teaching of EFL vocabulary to learners' culture.

Kabore, A. \& Nazortin, C. in "Critical Analysis of the Place and Importance of Literature in the Teaching / Learning of English and in School Leaving Certificate Examination in Burkina Faso from 1985 to 2018", analyse the types of texts given at the "Baccalaureate A" written examination in the last thirty years. In this study, quantitative and qualitative 
data are collected. Baccalaureate written English papers are the main focus of our collection. Teachers and supervisors are interviewed. The study is grounded on "Reader-Response Theory" which stresses the interactions between the reader and the text. The results of the study show that the great majority of texts proposed for "Baccalaureate A" examination, in the last thirty years, are non-literary texts.

Malgoubri, I., Sawadogo, M. \& Kambou, M. K.’s paper titled, “Digital Audio-visuals Aids and Listening in English as a Foreign Language Classrooms", is an experimental study which investigates the potential of digital audio-visuals to improve the listening skills of EFL learners in secondary schools in Burkina Faso. On the assumption that learners born around the year 2000 are digital natives, the researchers try integrating smartphone-friendly audio-visuals in their EFL classrooms in a four-week experiment involving one Experimental Group and one Control Group. The experiment aims at gauging the effectiveness of those aids operated via students' smartphones in improving learners' listening and speaking skills. Independent T-tests were used to compare the groups and Sample Paired TTests to make comparisons within groups. The study suggests that, if appropriately used, smartphones are excellent devices for language teachers and learners in this digitizing world.

Osei, R. N. \& Inusah, H.'s paper, “A Critique of the Images of Heaven in the Scriptures of the Abrahamic Religions: An Existentialist Perspective." Critically examines the scriptural images of heaven as captured in the Abrahamic religions - Judaism, Christianity and Islam - from the existentialist perspective. The paper argues that the idea of life beyond this earthly existence for all human beings in a specially prepared location by God for eternal happiness for those who obey His commands on earth called Heaven, as propounded by the Abrahamic Religions, throws up a lot of problems, especially from the existentialist perspective. The study concludes that the scriptures' constructs of heaven appear self-contradictory and fail to strike a chord with the contemporary image of the ideal society when perused from the existentialist perspective and should, therefore, be discarded.

Negedu, A. K.'s paper "Lexical Gaps and Ideological Shift in the Translation of Chinua Achebe's Things Fall Apart as "Le Monde S'effondre" in French." examines the ideological divergence between the title of the original text and the title of the translation, following an observation 
that in translating Chinua Achebe's Things Fall Apart, Michel Ligny translates directly Igbo terminologies, realities and beliefs into the French language. The paper concludes that the ideology that the translated title projects to French-readers is totally different from the ideology that the original title projects to English-readers.

Talburt, T., in "Political Transformation and Development in Africa: Lessons from Achebe's Things Fall Apart", formulates critical perspectives on the significance of Achebe's novel for the socio-political and economic transformation and development of the African continent. The paper challenges one of the central assumptions in this story that Africa falls apart as soon as it comes in contact with Europe. It questions aspects of political conservatism exhibited in Okonkwo who is suspicious of fundamental changes to his society. The discussion is based on the jollof rice principle of political hybridisation of development which proposes the amalgamation of Westernised and non-Western ideas and systems, in order to achieve economic development, rather than totally rejecting Westernisation in its entirety. The study uses examples of Western-style democracy and State intervention in Africa to demonstrate the significance of embracing some aspects of Westernisation through political hybridisation. 




\title{
A Critique of the Images of Heaven in the Scriptures of The Abrahamic Religions: An Existentialist Perspective.
}

\author{
Raymond Nonnatus Osei \& Husein Inusah \\ University of Cape Coast, Cape Coast, Ghana.
}

\begin{abstract}
In this paper, we critically examine the scriptural images of heaven as captured in the Abrahamic religions from the existentialist perspective. The three dominant Abrahamic religions: Judaism, Christianity and Islam opine that there is life beyond this earthly existence for all human beings and that God (their object of worship) has prepared a special place of eternal happiness for those who obey His commands on earth. This place is frequently referred to as the Kingdom of God, Heaven or Paradise. We argue that the above construct of heaven throws up a lot of problems, especially from the existentialist perspective. Some of these problems include the fact that these constructs of heaven eliminate all the challenges that stimulate human existentiality, throw into oblivion the scourging evils of boredom arising from the eternal passivity of existence in heaven and fail to lay down exactly the political structure and the legal status of the earthlings in heaven since a Kingdom presupposes a feudalist structure where there are kings, lords and serfs. We conclude by showing that the scriptures' constructs of heaven appear self-contradictory and fail to strike a chord with the contemporary image of the ideal society when perused from the existentialist perspective and should, therefore, be discarded.
\end{abstract}

Keywords: Abrahamic Religions; Boredom; Christianity; Existentialism; Heaven; Islam; Judaism; Kingdom; Scriptures.

\section{Introduction}

On this occasion of celebrating the life and achievements of our illustrious Professor and friend, we deem it appropriate to spend a few moments to reflect on a phenomenon that is all too familiar to us, and yet we 
wish it to be at least at arm's length. After all our dear Professor and friend is at the twilight of his life and death is a looming reality that he can't ignore.

As human beings, we are condemned to bite the bullet but we shudder at the prospects, and we do all that we can to escape, alas in vain, that finality. Hence, we have risen rich and soothing narratives that assure us of an afterlife that reduces the harsh finality into a transition: from the brutish human existence here on earth to a life of perpetual bliss bereft of pain and anguish. This is the incentive that the mainstream Abrahamic religions: Judaism, Christianity and Islam dangle before our eyes. It is a powerful motif that has urged the mass of the human population over time and across diverse cultures to endure brutish experience and senseless pain with equanimity. Their endurance and resilience are built on the hope that all this suffering is not for nothing; that there will be a just reward after this hardship. Otherwise, the world will be unfair, that your maker, Yahweh, God, Allah will be unjust.

So there is a powerful motivation for humans through their religious expression to hold up a form of existence befitting them even if that life happens to elude them here on earth. That, of course, is the hereafter life popularly known as Paradise, Heaven or the Kingdom of God. Let us then gaze into this imagined life of post-mortem existence and see what awaits us. We must warn you that the texture of the narratives of the hereafter life is rich and diverse, not only across the different religions but even within the same religion across epochs and geography. But due to lack of space, we will pick from each of the three religions the most popular and enduring images in contemporary times. But before then let's quickly take a look at some of these imagined conceptions of afterlife for the purposes of clarification and delimitation.

\section{The Concept of Afterlife}

The terminology "afterlife" may seem an ambiguous phraseology, given that its connotation is diverse across religious and demographic divide and even individual religions. Therefore, a suitable definition is needed in order to develop a meaningful discourse on any subject matter of the concept of an afterlife. One of the meaningful ways of defining the term is to construe it as the prolongation of life after biological or bodily death. This construal refers to a folk definition of the afterlife and has roots in the scriptures of the three Abrahamic religions. Another means of defining the afterlife is to construe it as the direct vision of God - what St. Thomas Aquinas calls "Visio beata" or the "beatific vision" of God. ${ }^{1}$ This also has roots in the scriptures. The third way of defining the concept of the afterlife is to suggest a neardeath-like experience where human consciousness and all sensory experiences 
are retained. This is what scholars have called the theory of natural afterlife (Ehlmann 2016: 2). ${ }^{2}$ Let us for the purpose of this presentation construe the term "afterlife" to mean the prolongation of consciousness after biological death or the continued existence of the self after bodily death. There are reasons for going on this trajectory - the second and the third ways of construing the concept of the afterlife, as shown above, are quasi-natural of some sort. For instance, the beatific vision is not necessarily meant to occur in the afterlife; it can also manifest when one is alive on earth in the form of direct self-communication with God. Hence, the way it is sketched fails to strike a chord with the picture we have of the eternal and self-direct communication with God in the hereafter. That is to say, it fails to capture St. Thomas Aquinas' intuition about eternal happiness when one is directly experiencing God after bodily death. The beatific vision is said to be an intellectual conception because it cautions believers from imagining the afterlife. It places in the minds of people a kind of perpetual suspense to prevent believers from trying to imagine what the afterlife would be like. ${ }^{3}$ This picture of heaven as beatific vision digresses from the way we intend to conceive of an afterlife, especially the heavenly portion of it that finds expression in the scriptures. Our focus is on examining the images of the heavenly portions of the afterlife to see if they are consistent with human existentiality.

In a similar vein, conceiving the afterlife in a natural sense is also not consistent with our position since we are examining some sort of supernatural afterlife - an imagined post-mortem existence after biological death - the one that occurs after the body and the soul are reunited for judgment in the hereafter. This latter version of the afterlife is consistent with some of the images of heaven depicted in the scriptures of the Abrahamic religions that we intend to examine. It depicts a kind of image that signifies the prolongation of life on earth after our bodily death. This to us raises an existential concern: if the afterlife is a continuation and manifestation of our earthly life, how would it accommodate human existentiality? Imagine a life without its usual and familiar challenges: making awkward choices, making decisions, the freedom to choose and take responsibility, the sense of achievement or failure, the fear of the unknown and the future. These are the challenges that stimulate human existentiality. In the absence of these challenges, the greatest existential evil that stares us in the face is boredom. Life without challenges is inevitably boring. Imagine a life that knows no needs, where efforts have no value or motivation. Is it any different from the life of a vegetable? What will be the normal life circle of the earthlings in this paradise? Is life worth living in Abrahamic heaven? 
Another crucial aspect we will explore in the scriptures' images of heaven concerns its political structure. Routinely referred to as the Kingdom of Heaven, one wonders what would be the political structure and legal status of the earthlings in this Kingdom. What rights and freedoms would they be entitled? For a kingdom evinces a feudalist structure of state where there are Kings, Lords/Barons and Serfs - each class having differing rights to property and other freedoms including political power. What then would be the status of the earthlings in God's Kingdom?

These are some of the things this presentation seeks to explore. We will show that the scriptural image of Heaven in the Abrahamic religions is: 1) self-contradictory when analyzed from the existentialist perspective and 2) strikes no chord with the contemporary image of the ideal society and should, therefore, be jettisoned.

As noted, we shall focus only on the heavenly aspect of the hereafter, what is usually referred to as the heaven or paradise - a place prepared by God for those who obey His commands while on earth. Now, let us take a brief look at some of these images of heaven in the three Abrahamic Religions.

\section{The Description of Heaven in Judaism}

Jews do not have a comprehensive description of heaven in the Torah. However, evidence abounds in the Judaist scriptures about the heaven and the nature of the hereafter, popularly known in Judaism as "Olam $\mathrm{Ha}-\mathrm{Ba}$ " "the world-to-come” (Wright 2000 p. 203).

Whoever contemplates four things, it would have been better for him if he had not come into the world - that which is above, that which is beneath, that which is before time, and that which will be hereafter (Mishnah, Hagiga 2:1).

As pointed out, the construal of heaven in Judaism is not that spectacular like that of the other two Abrahamic religions, Christianity and Islam. One does not encounter splendour and beauty of heaven in the Torah as we see in the Bible and the Quran. However, the Judaist text of Shi 'ur Qomah depicts heaven, the world-to-come, as a place that offers security from the tribulation of this world. The following are a few passages from the Judaist text of Shi 'ur Qomah that detail the description of the heaven in Judaism:

All who know this secret are certain to enter the world-tocome. The Holy One, Blessed be He, will rescue him from every evil thing - all kind of sorcery, the evil eye, the evil 
inclination, evil thoughts, all kinds of destroyers, all kind of damages, poverty and evil plans (Sepher HaQomah 24-27).

Whoever knows this measurement of his Creator and the glory of the Holy One, blessed be he, is secured in this world and in the world to come. He lives long in this world, and he lives long and well in the world-to-come. He does good in this world and in the world-to-come. Rabbi Ismael said, 'I and Rabbi Aqiba guarantees this, that in this world such a one has a good life and in the world-to-come a good name, but only if he recites this as Mishnah every day (Spher HaQomah 121-127). "Rabbi Jacob said, 'this world is like a foyer to the world-tocome; prepare yourself in the foyer so that you may enter into the banquet hall." (Mishnah, Avot 4:16).

The lesson drawn from the above literature is that the Judaists envisage a world that comes after this world where dwellers of this world-to-come will enjoy total security from the harsh troubles of this world, a place where one will enjoy a life of perpetual bliss.

\section{The Description of Heaven in Christianity}

For most Christians, heaven is the final goal of life. Hence, heaven is seen as an eternal abode of life where every comfort can be afforded without personal effort; where time ceases and where the righteous are rewarded for their good deeds. For instance, we find one of such descriptions of heaven in the Revelations, The final book of the New Testament. It reads:

Then one of the elders asked me, "These in white robes-who are they, and where did they come from?" I answered, "Sir, you know." And he said, "These are they who have come out of the great tribulation; they have washed their robes and made them white in the blood of the Lamb. Therefore, - they are before the throne of God and serve him day and night in His temple; and He who sits on the throne will shelter them with His presence. - Never again will they hunger; never again will they thirst. The sun will not beat down on them, nor any scorching heat. For the Lamb at the center of the throne will be their shepherd; He will lead them to springs of living water. And God will wipe away every tear from their eyes. (Revelation 7:14-17). 
Another verse of the Revelation offers a description of an eternal life devoid of sunlight in a timeless environment. It says the following: "There will be no more night. They will not need the light of a lamp or the light of the sun, for the Lord God will give them light. And they will reign forever and ever". (Revelation 22:5)

In Isaiah, there is a description of heaven showing life without bloodshed where human beings and wild animals live together in peace. This verse reveals an eternal abode devoid of all life challenges and tribulations; it reveals an environment bereft of competition, wants, and desires. It reads: "nations shall beat their swords into plowshares, and their spears into pruning hooks; nation shall not lift up sword against nation, neither shall they learn war anymore." (Isaiah 2:4).

One may find in the Bible two speculations about the Christian heaven in the New Testament. In one of such speculations, heaven is located in the clouds. This description is seen in the Thessalonians:

According to the Lord's word, we tell you that we who are still alive, who are left until the coming of the Lord, will certainly not precede those who have fallen asleep. For the Lord himself will come down from heaven, with a loud command, with the voice of the archangel and with the trumpet call of God, and the dead in Christ will rise first. After that, we who are still alive and are left will be caught up together with them in the clouds to meet the Lord in the air. And so we will be with the Lord forever. Therefore encourage one another with these words. (1 Thessalonians 4:15-18).

In contrast to this construal of heaven as beyond the sky, there is another speculation of heaven, The "New Jerusalem that comes down from heaven". The writer of the Revelations reports the following:

I saw the Holy City, the New Jerusalem, coming down out of heaven from God, prepared as a bride beautifully dressed for her husband. And I heard a loud voice from the throne saying, Look! God's dwelling place is now among the people, and he will dwell with them. They will be his people, and God himself will be with them and be their God. He will wipe every tear from their eyes. There will be no more death or mourning or crying or pain, for the old order of things has passed away (Revelation 21:2). 
This shows that God will not transport the righteous to heaven as suggested in the Thessalonians but will remodel the earth into an Edenic paradise where righteous Christians will have an eternally joyous and comfortable life.

\section{The Description of Heaven in Islam}

Like Judaism and Christianity, heavenly speculations are an integral part of a Muslim's spiritual life. Generally, Muslims believe that at death, people will be judged on the basis of their deeds on earth. Those found to be righteous will inherit paradise, "Al-Jana" and those found to be impure will be transported to the hell of perpetual flame, "Jaha' nam." Pious Muslims are told to envisage a paradise adorned with every stripe of beauty one could imagine. The Quran depicts the dwellers of heavens as royals robed in royal garments according to ranks who enjoy every comfort without any effort:

"They will recline (with ease) on Thrones (of dignity) arranged in ranks..." (52: 20).

They and their associates will be in groves of (cool) shade, reclining on Thrones (of dignity). Every fruit (enjoyment) will be there for them; they shall have whatever they call for (36:5657).

In a lofty Paradise, where they shall neither hear harmful speech nor falsehood. Therein will be a running spring. Therein will be thrones raised high, and cups set at hand. And cushions set in rows, and rich carpets (all) spread out (88:1016).

\section{Existential Challenges of Heaven}

To make sense of these images from the existentialist perspective requires that we first define the term existentialism. The nomenclature is notorious for what it is not rather than for what it is. In other words, existentialism is not a body of doctrines. In fact, existentialists share a common character of opposition to any doctrine. It started as a movement against the traditional method of philosophizing represented in Plato, Aristotle and culminating in Rene Descartes. In brief, existentialists railed against the formalism and abstract and impersonal orientation of traditional philosophy that was oblivious of the real material and psychological needs of the living person. 
A human being is born, grows up and becomes a self-conscious person. It is only when she/he becomes a self-conscious person that she/he is recognized as an autonomous and moral being. Coming of age brings with it a host of freedoms and responsibilities. From the existentialist perspective, it is these freedoms and responsibilities that define what life is all about. The individual in this familiar world is confronted with choices on a daily basis: when to sleep, when to wake up, when to go to work or not go to work, etc.

Besides these routine choices we are equally confronted with situations when we have to make momentous and at times, unpleasant choices - choices whose outcomes often cannot be anticipated. For the existentialists, the hallmark of living a life is the freedom to make choices and take responsibility for the choices we make. In other words, it is about a history of the challenges that confronted the subject and how she/he strove to overcome those challenges. That is how we grade the famous and not so famous and the ignoble. It is by our achievement that we are remembered. How then are we to grade the life in Paradise, Heaven or the Kingdom of God?

From the narratives of the images of heaven presented in the three scriptures, what is striking about post-mortem existence is a life free from the pains and travails of life that are all too familiar here on earth. It is a life that apparently doesn't require any effort for enjoying perpetual bliss - a life of eternal happiness without risks, without challenges. Trapped in a perpetual cycle of ecstasy evokes the image of a subject soaked in opioid solution who drifts away on the wings of a butterfly, forever for eternity - a life without effort and no sense of achievement.

Let us borrow a page from the founder of the existentialist frame of thought, Soren Kierkegaard. In his novel titled, Either / Or, he depicts three possible forms of life that each individual is bound to choose one.

1. The aesthete: You have only one life to live, so you might as well arrange to make it enjoyable. It is true that the kind of ironic detachment this requires means that life is ultimately meaningless and that there are no serious choices, but that's just how life is.

2. The ethicist. life is neither this way nor that; it all depends on what you do with it. And that is a matter of choice, the sort of serious choice that constitutes a continuing self. You are what you make of yourself. And far from being meaningless nothing could possibly matter more.

3. The Christian: you can't successfully create yourself. We are all failures at this task. What is required is an acknowledgement of this fact, together with faith in God's forgiveness through Christ. In this way we can come to accept ourselves in spite of our unacceptability; only thus can we be free simply to be ourselves (Kierkkegaard 1987). 
Now, running through these three forms of life is the imperative of making choices that would define your person. It is the availability of choice that differentiates a person from a non-person, say, a vegetable. At least engaged in the business of making a choice rids oneself of what is considered as the greatest evil: boredom. Kierkegaard's notes as follows:

Boredom is the root of all evil. This can be traced back to the very beginning of the world. The gods were bored; therefore they created human beings. Adam was bored because he was alone; therefore Eve was created. Since that moment, boredom entered the world and grew in quantity in exact proportion to the growth of the population. Adam was bored alone; then Adam and Eve were bored together; then Adam and Eve and Cain and Abel were bored en famille. After that, the population of the world increased, and the nations were bored en masse. To amuse themselves, they hit the notion of building a tower so high that it would reach the sky. This notion is just as boring as the tower was high and is a terrible demonstration of how boredom had gained the upper hand (Kierkegaard 1987, pp. 285-286).

For the existentialist then boredom remains a major vice that must be avoided at all costs. Imagine an afterlife where virtually all sustainable choices have been made for you. There would be no need for exertion because there is virtually nothing to achieve. All our desires are fulfilled in a twinkle of an eye. And there is apparently no restraint in satisfying your desires including things such as wine, table and bed and this feast can go on forever. This is nothing short of life of sloth and indolence portrayed in John Keats "Ode on Indolence" (Vendler 1985).

One may raise a protest that such imagined afterlife depicted in the scriptures is hinged on the choice we have made on earth. Hence, the life of perpetual bliss to be enjoyed in our post-mortem existence is the reward of the choice we made to endure the pain of this life with equanimity. This protest may be right. But this flies in the face of the objective of this paper. We do not deny that God may reward good deeds with the splendour, beauty and eternal comfort in the hereafter. But the crucial question that we seek answers is: what is the nature of this eternal life in heaven? Is this life worth living, given that it is bereft of choices, risks and decision-making which characterize human existence? Our contention is that not only is such life not worth living but it is also practically inconceivable. 
Life cannot be lived in practice without the routine challenges of making choices, taking decisions and risks. In short, life cannot be lived without engaging with activities and tools that keep us frequently busy for the purposes of eschewing boredom in the world. This reminds us of one of the famous existentialist of the twentieth century, Martin Heidegger. He argues in Being and Time that being a person is necessarily not about what stuffs you are made up of. Rather, it is defined in terms of being engaged in projects, being involved with others and using tools. To live is to dwell in the world which means to be engaged with events within and outside our vicinity. It is not to be just located in the world without any engagement. Heidegger opines that:

Being-in-the-world has always dispersed itself or even split itself up into definitive ways of Being-in. The multiplicity of these is indicated by the following examples: having to do with something, producing something, attending to something, and looking after it, making use of something, giving something up and letting it go, undertaking, accomplishing, evincing, interrogating, considering, discussing, determining... (Heidegger 1967, p. 83).

These activities cited above determine our engagement with the world designed to eschew boredom. Our routine engagement with the world is what determines our being, and it is the fundamental or the essential element upon which our very life as human beings is constructed. Juxtapose this life with the life of hereafter depicted in the scriptures. How do we address the existential challenge of boredom in heaven if everything can be achieved without any human exertion? How is a life worth living in heaven without personal engagement with the world within our ken?

Let us consider another image of heaven that is often seen in many places of the scriptures. In the scriptures, heaven is cast in the patriarchal or feudalistic terms and frequently referred to as the Kingdom of God. For instance, there are about sixty-three Bible verses that make reference to the Kingdom of God and His Holy Throne. Jesus is reported to have told Pilate in the Book of John, 18:36 that "My Kingdom is not of this world".

In the Quran, the following two verses make reference to the Kingdom of God:

Say, 'O Allah! Possessor of the Kingdom! You give the Kingdom to whom You will, and You take the kingdom from whom You will”' (Quran 3:26). 
"Say, 'I seek refuge with Allah, the Lord of Mankind, the King of Mankind, the God of Mankind.... (114:1).

As noted, the reference to Kingdom envisages a feudal system where there are Kings, Lords (who are vassals to the King) knights (who are vassals to the Lords) and the serfs or peasants (who represent the people down the social ladder). The implication is that this construct of heaven is couched in feudalist terms depicting a kingdom ruled over by God, the Absolute Monarch, who will cede territories in heaven to his lords, who in turn will allow the peasant class to use tracts of land in heaven in return for loyalty. After all, this is the construct of "kingdom" we inherited from the medieval periods in Europe.

The feudalist notion of governance in heaven raises some few concerns, and we shall address these concerns in the remainder of the presentation. First, the earthly beings' status in this construct of heaven is obviously cast in stone. There would never be social mobility from serfdom to aristocracy. There would be no possibility of state transformation from a kingdom to a republic of free citizens. Consider the possibility of an afterlife of eternal existence where you will not have the freedom of dissent, no prospect of ever enjoying the status of an angel and no sense of achievement. And the frightening thing is that this state of indolence and passivity drags on forever.

Second, it contradicts the very notion of heaven that is supposed to provide an eternally blissful rest devoid of the tribulations and anguish for the righteous. The idea of the kingdom of heaven where there are serfs and lords who bear loyalty to God, the Absolute monarch, does not sit pretty well with most of the other scriptures' narratives of heaven. If heaven is a kingdom, then there is a kind of subtle admonition of the dwellers of heaven to obey the powers above and try to operate within God's commands. The implication is that even in heaven one is not a free citizen because she/he must live perpetually within the confines of God's commands. This renders the supposed freedom to be enjoyed in heaven a grand illusion. So, where lies the blissful eternal rest if in heaven dwellers will be subjected to perpetual serfdom under everlasting obedience to God, the Grand patriarch?

A third concern is that this notion of heaven fails to strike a chord with the ideal contemporary society. Though feudalism existed many centuries ago, it flourished in the medieval European societies of the $10^{\text {th }}$ and $13^{\text {th }}$ centuries CE. Our contemporary sociopolitical system is no more feudalistic; it is a republic where governance is not considered a private concern of the rulers. In the republic, as it may be found in many contemporary nations, primary positions are not inherited but are attained through democracy, oligarchy and 
aristocracy. So, how do people who presently live (or have lived) in a predominant democratically sociopolitical culture fit into this imagined feudalist political culture? Would it not sound like dying a free man and living in captivity in the afterlife for eternity? Let us ponder over this.

\section{Conclusion}

The notion of an afterlife is a subject matter that is popular with the three Abrahamic religions. The scriptures of these religions are replete with the magnificent depictions of the afterlife, especially the world-to-come (for Judaist) heaven (for Christians), and paradise (Muslims). This heavenly abode is supposed to be a place for only the righteous, who have deprived themselves of the worldly desire in search for this heavenly abode. They expect to enjoy a life of perpetual bliss, devoid of pain, anguish, tribulations and terror of this earth in this new home. Such is the splendour of heavens depicted in these scriptures. We have said in this paper that these images of heaven throw up a plethora of existential challenges. How is life in heaven worth living without all the existential challenges, like boredom, anguish, pain, disappointment, unrequited love and so on. How is life worth living under conditions where one gets everything at his disposal without exertion? We have said that such a life could at best be described as a life of the vegetable. We have also opined that the reference to heaven as a kingdom of God envisages a feudalist system where there is a king with absolute power who is perpetually worshipped by the serfs and the Knights. This view is not consistent with the narratives of the image of heaven and also does not strike a chord with the socio-political system of contemporary societies and must be jettisoned.

\section{Notes}

1. A. E. Taylor (1974, p. 64).

2. There are several books on the market that provide varied accounts of this type of near death experiences. See Alexander, E. (2012)

3. This way of conceiving afterlife is seen in 1 Corinthians 2:9 "eye has not seen, and ear has not heard, and what has not entered the human heart, (is) what God has prepared for those who love him." 


\section{References}

Alexander, E. (2012). Proof of heaven: A neurosurgeon's journey into the afterlife. New York: Simon \& Schuster.

Cohen, M. S. (1985). The Shi 'ur Qomah: Texts and Recensions. Tubingen: J.C.B. Mohr/Paul Siebeck.

Ehlmann, B. K. (2016). The theory of a natural afterlife: A newfound, real possibility for what awaits us at death. Journal of Consciousness Exploration \& Research 7(11): 931-950

Heidegger M. (1967). Being and Time. Trans. John Macquarrie and Edward Robinson. Oxford: Basil Blackwell

Kierkegaard S. (1987). Either/Or, Vol. 1 \& 2. Trans. Howard V. Hong \& Edna H. Hong. Princeton, NJ: Princeton University Press.

Taylor, A. E. (1947). The Christian hope for immortality. New York: Macmillan Vendler, H. (1985). The odes of John Keats. Harvard: Harvard University Press Wright J. E (2000). The early history of heaven. Oxford: Oxford University Press 
